\title{
Paediatric case of endobronchial foreign body migration to the gastrointestinal tract
}

\author{
Bhavesh Vijay Tailor 지 , 1,2 Rachael Collins (1) , ${ }^{1,2}$ Abdul Mohammed, ${ }^{2}$ Andrew Bath ${ }^{2}$
}

${ }^{1}$ Norwich Medical School, University of East Anglia, Norwich, UK

${ }^{2}$ Department of Otolaryngology, Norfolk and Norwich University Hospital NHS Trust, Norwich, UK

\section{Correspondence to Dr Bhavesh Vijay Tailor; bhavesh.tailor@cantab.net}

Tim David Prize Session, Section of Paediatrics \& Child Health, The Royal Society of Medicine, Webinar, Tuesday 16 February 2021.

Accepted 8 March 2021
Check for updates

(C) BMJ Publishing Group Limited 2021. No commercial re-use. See rights and permissions. Published by BMJ.

To cite: Tailor BV, Collins R, Mohammed A, et al. BMJ Case Rep 2021;14:e240858. doi:10.1136/bcr-2020 240858

\section{DESCRIPTION}

We report a case of a 10-year-old girl who presented with a new-onset cough after aspirating a paperclip several hours earlier. She was not in respiratory distress, had normal breath sounds on auscultation and was maintaining adequate oxygen saturations. Chest X-ray demonstrated a $2.5 \mathrm{~cm}$ paperclip in the left main bronchus (figure 1).

She was admitted under the care of the ear, nose and throat team and taken to theatre on the same day for rigid bronchoscopy. The airways were carefully inspected to the level of the segmental bronchi in both lungs. However, no foreign body (FB) was found. Intraoperative fluoroscopy showed the paperclip to be in the stomach (figure 2). The paediatric surgical team were informed and the patient was returned to the ward. When we questioned the girl on the following morning ward round, she reported having an intense bout of coughing shortly prior to bronchoscopy, sensed the paperclip in her throat and proceeded to swallow it. She had not reported this to the medical or nursing staff at the time. The girl was then discharged home with safety netting advice provided to the parent.

Paediatric foreign body aspiration (FBA) is a potentially life-threatening emergency presentation. Missed or delayed diagnosis can result in respiratory complications and lead to significant morbidity. The incidence of FBA is highest among young children ( $\leq 3$ years). Organic material is most commonly aspirated, especially fragments of nuts or seeds. The most common location for FB

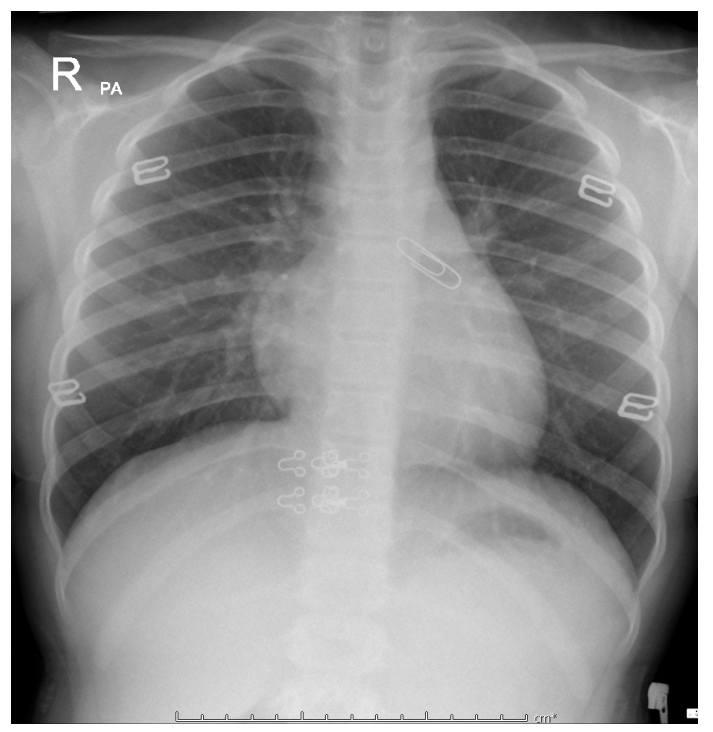

Figure 1 A posteroanterior (PA) chest radiograph showing a paperclip located in the left main bronchus.

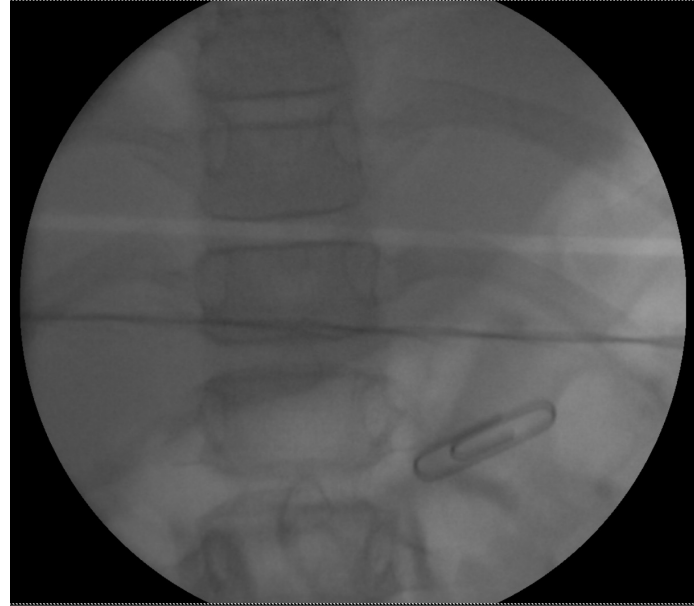

Figure 2 Intraoperative fluoroscopic image taken after bronchoscopy showing a paperclip to the left of midline in the stomach.

impaction is in the right main bronchus, followed by the left main bronchus and less commonly in the lobar bronchi, trachea and larynx. ${ }^{12}$

There is a rare possibility of $\mathrm{FB}$ migration within the tracheobronchial tree, likely caused by induction of anaesthesia or coughing. This is particularly true in the case of inorganic FB since they do not induce a significant inflammatory tissue response. ${ }^{3}$ Secondary mediastinal migration following apparent aspiration of a sharp FB is also reported in the literature, presumably by penetrating the bronchial wall. ${ }^{4}{ }^{5}$ However, spontaneous expectoration of an FB from the lower airways up into the oropharynx and immediate ingestion into the gastrointestinal tract is an unusual phenomenon. We identified five such cases in the published English-language literature, ${ }^{6-10}$ all involving a sharp metallic object (needle $(n=3)$, pin $(n=1)$, screw $(\mathrm{n}=1)$ ), with a median patient age of 8 years (range: 2-14 years) and a male to female ratio of $1.5: 1$. Migration of the FB into the gastrointestinal tract went unnoticed in 3 of 5 cases.

Paediatric FBA can be an overwhelming experience for both the patient and guardian. Care should be taken to alleviate parental and child anxiety in order to remove barriers to communication and reduce the risk of critical information being withheld. In this case, the clinical presentation and radiographic findings prompted early intervention with rigid bronchoscopy per standard of care for tracheobronchial FB. Waiting for spontaneous FB expulsion is not recommended since this is a rare phenomenon and the complication rate increases 
with late intervention. However, this case highlights the importance of educating the parent or guardian and the medical team about the possibility of spontaneous expulsion and the need for close monitoring. If there is clinical uncertainty regarding the location of a radiopaque $\mathrm{FB}$, repeat imaging should be strongly considered before proceeding to an invasive procedure under general anaesthetic.

\section{Learning points}

- An inability to locate a radiopaque foreign body (FB) during rigid bronchoscopy should alert the clinician to consider gastrointestinal tract migration. There should be a low threshold for repeat imaging in the perioperative period.

- Once the FB is confirmed to be situated in the gastrointestinal tract, the paediatric surgical team should be informed. The child should then be managed according to local guidelines for swallowed foreign bodies.

- Expectant management is not recommended in cases of suspected or confirmed FB aspiration. Spontaneous expulsion of an endobronchial FB is a rare phenomenon.

Contributors BVT: involvement in patient care, acquisition of data and analysis, drafting, revising, final approval, accountability for all aspects of the work. RC: involvement in patient care, data analysis and interpretation, revising, final approval, accountability for all aspects of the work. AM: involvement in patient care, conception and design, data analysis and interpretation, revising, final approval, accountability for all aspects of the work. AB: involvement in patient care, conception and design, data interpretation, revising, final approval, accountability for all aspects of the work.
Funding The authors have not declared a specific grant for this research from any funding agency in the public, commercial or not-for-profit sectors.

Competing interests None declared.

Patient consent for publication Parental/guardian consent obtained.

Provenance and peer review Not commissioned; externally peer reviewed.

\section{ORCID iDs}

Bhavesh Vijay Tailor http://orcid.org/0000-0001-7534-5183

Rachael Collins http://orcid.org/0000-0001-5812-0767

\section{REFERENCES}

1 Sink JR, Kitsko DJ, Georg MW, et al. Predictors of foreign body aspiration in children. Otolaryngol Head Neck Surg 2016;155:501-7.

2 Tan HK, Brown K, McGill T, et al. Airway foreign bodies (FB): a 10-year review. Int J Pediatr Otorhinolaryngol 2000:56:91-9.

3 Wadhera R, Gulati SP, Kalra V, et al. Migrating foreign body in the bronchus. Otolaryngol Head Neck Surg 2011;145:701-2.

4 Luh SP, Lee YC. Foreign body aspiration with mediastinal migration and superior vena cava penetration. Chest 1994;105:1923-4.

5 Łoś-Rycharska E, Wasielewska Z, Nadolska K, et al. A foreign body in the mediastinum as a cause of chronic cough in a 10-year-old child with asthma. J Asthma 2021:58:276-80.

6 Abraham ZS, Kahinga AA, Mapondella KB, et al. Spontaneous expulsion of an intrabronchial sharp metallic foreign body and migration to the gastrointestinal tract at Muhimbili national Hospital: case report and literature review. Int J Surg Case Rep 2020;72:423-5.

7 Aihole JS, Babu MN. Spontaneous migration of airway foreign body to the gastrointestinal tract. Indian Pediatr 2015;52:534-5.

8 Brand PLP, Rosingh HJ. The "wandering needle.". Pediatr Pulmonol 2003;35:152-4.

9 Sayedi SJ, Gharavi Fard M, Khakshour A. Case report of a vanished aspirated foreign body; cough may be more helpful. International Journal of Pediatrics 2019;7:9363-7.

10 Graffstädt H, Dieckow B, Grüber C, et al. Christmas surprise: the unnoticed journey of a needle-from bronchus to intestine. Respir Med 2005;99:1600-2.

Copyright 2021 BMJ Publishing Group. All rights reserved. For permission to reuse any of this content visit

https://www.bmj.com/company/products-services/rights-and-licensing/permissions/

BMJ Case Report Fellows may re-use this article for personal use and teaching without any further permission.

Become a Fellow of BMJ Case Reports today and you can:

- Submit as many cases as you like

- Enjoy fast sympathetic peer review and rapid publication of accepted articles

- Access all the published articles

Re-use any of the published material for personal use and teaching without further permission

Customer Service

If you have any further queries about your subscription, please contact our customer services team on +44 (0) 2071111105 or via email at support@bmj.com.

Visit casereports.bmj.com for more articles like this and to become a Fellow 